written, with a more detailed account of the appearances resulting from the paralysis of individual muscles, and the new classification of malignant disease of the pharynx is excellent.

In spite of additions to certain sections the length of the book has been increased by only some 30 pages, owing to judicious pruning in the space devoted to conditions which are less frequently seen at the present time. Most of the illustrations have been seen before, and some belong to the original edition, while a great deal of the text remains unchanged. Much of it bears the stamp of the man who used to stand up at a meeting to say: 'The solution of this problem is quite simple. If you will buy a certain book (price two guineas) you will find written on page etc., etc., etc.' Alas, the price has increased, but the publishers are to be congratulated on maintaining the high standard of the previous editions in spite of shortage of materials.

The wealth of knowledge and experience presented is extraordinary and, for those who wish to pursue the more obscure problems, the bibliography, which has been completely revised, gives an abundance of references. The book is strongly recommended to all interested in the subject.

$$
\text { A.B.-D. }
$$

\section{TEXTBOOK OF GYNAECOLOGY}

By J. H. PeEL, M.A., B.M., B.Ch., F.R.C.S., F.R.C.O.G. 3rd Edition. Pp. xvi +477 , with 2 I 9 illustrations. London: William Heinemann. 1950. $24 \mathrm{~s}$.

This book fulfils all the essentials of a textbook on gynaecology for students and practitioners. It is thoroughly up to date without containing unproven experimental work, yet sufficient mention of recent developments is made to hold the interest. The arrangement is orderly and the subject matter is presented in a very readable fashion.

The drawings and microphotographs, of which there is a thoroughly adequate number, are of high standard and go far in illustrating an already clear text.

R.C.P.

\section{RECENT ADVANCES IN THE PHYSIOLOGY OF VISION}

By Professor Hamilton Hartridge, M.A., M.D., M.R.C.P., Sc.D., F.R.S. Pp. xii +401 , with 236 illustrations. London: J. \& A. Churchill, Ltd. $1950.25 \mathrm{~s}$.

Research into the problems of visual sensation has attracted considerable attention among physiologists in recent times. Since the standard English textbooks were written new approaches along anatomical, physiological and physical lines have developed and have resulted in a reorientation of our attitude to many of these basic problems.

The publishers are to be congratulated upon the acquisition of the Director of the Physiology of
Vision Research Unit to introduce the first volume on the subject in the Recent Advances series. $\stackrel{\mathbb{Q}}{ }$ Students of Ophthalmology, as well as physiologists, $\stackrel{c}{\complement}$ will welcome its appearance and will find, in its eight chapters, a comprehensive survey of the newer $\overrightarrow{\vec{S}}$ methods of investigation in use, and of the knowledge in which they have resulted. The clarity of $\frac{C}{0}$ the text is considerably enhanced by the inclusion of excellent descriptions of the older work.

H.E.H.

\section{THE FILTERABLE VIRUSES}

By Francis O. Holmes. Pp. xxiii + r6o. London: Ballière, Tindall and Cox. 1948. 20s.

This book, published as a supplement to Bergey's Manual of Descriptive Bacteriology, puts forward a classification of the filterable viruses together with of a binomial nomenclature according to Linnaeus. $\dot{\omega}$ The viruses are treated as members of one order 8 and are sub-divided into three main sub-orders, on namely, bacterial, plant and animal viruses. These $V$ are further sub-divided into families, genera and species.

Two main criticisms can be made against this classification. Firstly, binomial nomenclature is both unwieldy and unnecessary at the present time. Secondly, and this is the main criticism, the classivi fication is based upon symptomatology which is $\mathbb{Q}$ assuredly the one basis upon which it should ngt $\vec{\theta}$ be made. It is open to question whether the tinge of has yet come for a classification of the filterabate. viruses to be made; if it has, then the first proble is to decide on what basis that classification should be made. This is a problem for discussion and agreement on an international basis. This book will undoubtedly stimulate action towards that end.

J.A.D.

\section{CLINICAL NUTRITION}

Edited by NoRMan JolifFe, M.D., FrederICK Tisdall, M.D., and Paul R. Cannon, M.D. 3 Pp. xvi +925 , with 78 tables and 127 illustrations, 61 in colour. London: Cassell \& Co., 3 Ltd. I 950 . 90s.

It is now well known that proper nutrition in 3 addition to its role in the prevention of nutritional 0 diseases is not only a major safeguard against all $\supset$ types of illness, but is also one of the most valuable $\frac{}{8}$ forms of clinical treatment of disease. Until comparatively recently the nutritive values of the average diets of hospital patients were considerably below their nutritional requirements, but where $\tilde{O}$ the modern treatment of special diets has been pre-N scribed marked improvement in many cases was soon manifest.

The vast literature of nutrition is largely scattered throughout a diversity of technical and medical ${ }_{\mathscr{C}}$ periodicals which are not readily available to the ${ }^{-}$ general practitioner and it is becoming increasingly difficult to and the appropriate information at? 